\title{
Ibn 'Arabī, Ibn Qayyim al-Jawziyya, and the Political Functions of Punishment in the Islamic Hell
}

\author{
Samuela Pagani
}

\begin{abstract}
Who is the man here below who has never committed a sin, tell me? He who had never committed one, how could he have lived, tell me? If, because I do evil, you punish me with evil, what difference is there between you and me, tell me?

'UMAR KHAYYĀM' 1
\end{abstract}

The eternity of hell is among those issues on which Ibn Taymiyya (d. 723/1328) and Ibn Qayyim al-Jawziyya (d. 751/1350) opted for an original theory, one that is in contrast to established Sunni doctrine. From the perspective of the latter, hell is eternal for infidels, while the faithful dwell there only temporarily. The two Hanbali theologians, instead, argued in favour of the eventual annihilation of hell. Numerous recent studies that have analysed this theory have also examined its relationship with that of Ibn 'Arabì (d. 638/1240), for whom the punishment, but not hell, is finite, thus prompting interesting cues for comparison. $^{2}$

The comparison is legitimate, given that the stance taken by the two Hanbali authors can, in part, be explained as a reaction to Ibn 'Arabīs theory. Ibn alQayyim refers to it explicitly, clearly distancing himself while at the same time implicitly acknowledging his debt. ${ }^{3}$ Here, I would like to return to the issue,

1 Khayyām, Rubāiciyāt, tr. Fitzgerald 70 n. 2.

2 Al-Manā'ī underscores the points of concordance between the three authors, from the perspective of a cautious rehabilitation of Ibn 'Arabī in a Salafi modernist intellectual context. See Manā̄ī, 'Aqīida. Khalil considers Ibn 'Arabỉ's theories and those of the Hanbalīs as alternative visions of "universal mercy." See Khalil, Salvation 73. He concludes, however, that Ibn Taymiyya "moved beyond Ibn 'Arabī's quasi-universalism." See ibid., 86. At least in as much as concerns Ibn al-Qayyim, Ajhar arrives at a similar conclusion: yumkinu al-qawl inna Ibn al-Qayyim qad fāqa Ibn 'Arabīfì hādhihi al-mas'ala wa-dhahaba ab'ad minhu. See Ajhar, Su’āl 263. See also Hoover, Theodicy 46-8; idem, God's wise purposes 126.

3 Ibn al-Qayyim quotes a long passage from Ibn 'Arabì (Fușusș i, 93-4) where the latter argues in favor of the possibility for God to renege on his threat of punishment (khulf al-waid). 
focusing on an aspect of Ibn 'Arabì's eschatology which may prove useful in comparing the two theories further: the concept of punishment that lies at the root of Ibn 'Arabï's theory. What does infernal punishment actually involve? And which legal model of punishment does it match?

Ibn 'Arabì's own speculations on the nature of eschatological castigation are part and parcel of his reflections about the notion of punishment, which are in turn a recurring motif in his legal thought. For the topic to be covered suitably, a thorough catalogue and correlation of the many relevant passages scattered throughout Ibn 'Arabỉ's entire works would be necessary. The task would be all the more difficult because Ibn 'Arabī's writing is more akin to hermeneutics than to philosophy or theology. His aim, in the field of eschatology as elsewhere, is to disclose the multiple aspects (wujūh, lit. "faces") of the Revelation rather than giving a systematic presentation of doctrine. Moreover, without having to subscribe to any schools, Ibn 'Arabī is able to find a wajh șahịh (an aspect that is real and true) in the disparate opinions voiced in Islamic systematic theology (kaläm), philosophy (falsafa) and Sufism, including those distrusted by the heresiographers.

My own knowledge does not extend far enough for such an undertaking; I will, however, endeavour to determine major themes. The positions taken by Ibn Taymiyya and Ibn al-Qayyim, following the principle that things can be discerned through their opposites, will help identify these themes, that is to say those sensitive points in Ibn 'Arabī's outlook that may have triggered a creative response in the two Hanbalis. Among these issues, the notion of punishment appears to me to be of particular relevance.

Thus, prior to illustrating some of Ibn 'Arabì's ideas on the topic (sections 3 and 4), Ibn al-Qayyim's position will be covered, dwelling primarily on the jurisdictional-political element (section 2). We cannot proceed, however, without first of all covering the essential features of the ongoing debate on the eternity of hell in the realm of Islam before the seventh/thirteenth century (section 1). I make no pretence of exhausting the topic, but doing so will allow me to clarify the approach taken in this paper.

See Ibn al-Qayyim, Hād $\bar{\imath}$ 352. Ibn al-Qayyim supports the same theory. See ibid., 383-4. Ibn al-Qayyim remarks that one should not reject the theory of the annihilation of the Fire only because "innovators" have supported it (ibid., 364). In fact, both Ibn 'Arabī and Ibn Taymiyya limit binding consensus to the Salaf, making room for the adoption of opinions rejected as "innovations" by the majority of the Sunni schools. Finally, it should be remembered that Ibn Taymiyya, at least in his formative years, held a favorable view of Ibn 'Arabī. See Ajhar, Su'āl 119-21; Khalil, Salvation 87; Manāīì, 'Aqīda 101. However, Ibn Taymiyya rejected Ibn 'Arabī's views of hell. See ibid., 96; Chodkiewicz, Procès 102. 


\section{Universal Salvations}

Quranic exegesis (tafsir), the hadith and the kaläm tradition offered a vast and varied arsenal of arguments in favour of the end of hell; Ibn 'Arabī, Ibn Taymiyya and Ibn al-Qayyim take advantage of all of these arguments in different degrees. The underlying idea is that, in God, mercy prevails over wrath and that it will triumph at the end of time. Going into specifics, these can be listed as follows: God will most certainly honour His promise of reward but is not obliged to fulfil His threats; when the Quran refers to the "eternity" of hell, the term can be taken to mean a "long period"; an eternal penance would not be rightful, as it would be inconsistent with the offence, which was committed in a limited time-span; penance has a purifying function and therefore has a finite duration; the intercession of the faithful and the Prophet, or God's own direct intervention, can save sinners. There are also isolated traditions that announce the final emptying and annihilation of hell. ${ }^{4}$

According to Sunni authors, these arguments apply only in the case of sinning believers, not in that of unbelievers, but nevertheless, they appear to offer an opening for universal salvation. All of these arguments are actually echoed by Christian supporters of universal salvation, a position rejected by Augustine in book 21 of City of God. Augustine's well-known rejection helps us hone in on the various nuances this concept can take on. The targets of his criticism are on the one hand Origen, whose position had been condemned by the church, and, on the other, "tender-hearted" Christians whom Augustine does not regard as heretics, but as misguided by a misplaced compassion for the damned ( $\mathrm{De} C \mathrm{C}$. Dei 21.17). ${ }^{5}$ These two tendencies have distinctive features. Origen's doctrine of apocatastasis (restoration) fits into a framework of optimistic theodicy, sharpened by the dispute with dualists: evil is accidental and transitory and is, in the end, removed. The trials of hell have a purgative and therapeutic function whose duration is limited. Ultimately leading to the total destruction of evil, they help to restore the original harmony and unity of creation. ${ }^{6}$

The "tender-hearted," in turn, split into two distinct groups. The first are universalists who envisage the salvation of unbelievers through the intercession of the saints (De Civ. Dei 21.18). ${ }^{7}$ This act of mercy, rather than a necessary

4 For an in-depth analysis of exegeses of verses on the eternity of hell in early tafsirs see Hamza, Hell 74-119. For further developments in exegesis, see Manāî̀, 'Aqīda; Khalil, Salvation. Cf. also Pagani, Vane speranze 184-93 (tr. 286-90).

5 Bauckham, Fate 151.

6 Daley, Hope 48-6o.

7 Bauckham, Fate 147, 155-6. 
return to a primordial state, is the outcome of a salvation history in which the saints' mediation plays an essential role. In this context, much is made of the conflict between justice and mercy, and castigation in hell is seen more as retributive punishment that can be revoked by virtue of the victim's forgiveness than as a necessary corrective penalty. ${ }^{8}$ The source of this view may have been the Apocalypse of Peter, ${ }^{9}$ where the legal paradigm underlying the unlimited possibility of forgiveness may have been retaliation. ${ }^{10}$ In Muslim eschatology this chance of salvation is foreseen, but it is limited to believers. Al-Nasafì (d. 508/1114), for example, suggests that the Quranic verses on retaliation allow believers to hope for salvation. ${ }^{11}$ Here, private justice, which helps to right wrongs, only applies to the believing "brothers," and not to the unbelievers, whose irreparable wrongdoing is punished in eternity. This two-tiered justice brings to mind Plato's afterlife where the punishment of "curable" sinners comes to an end when their victims have been contented and appears principally to regard private offences, while the exemplary punishment of the "incurable," which is eternal, is inflicted mainly on tyrants, whose wrongdoing afflicts the polis. ${ }^{12}$

The second category of "tender-hearted" refuted by Augustine are those who wish to extend the scope of salvation to people who profess Christian faith, but who have lived wicked lives (De Civ. Dei 21.19-21). ${ }^{13}$ This last tendency, which we can call confessional universal salvation, and which is echoed in the 'catholic' tendency voiced by Jerome "at his most generous,"14 finds an exact match in the position that the traditionalists succeeded in enforcing at the end of a long struggle by basing themselves on the authority of the Sunna. Feras Hamza has given us a clear sketch of the polemic atmosphere of the early centuries of Islam in which the "People of the Sunna and the Community" (ahl al-sunna wa-l-jamāa $a$ ) developed their doctrine of temporary hell while

\footnotetext{
$8 \quad$ Ibid., $132-48$.

9 Ibid., $149-59$.

10 For a critical appraisal of this interpretation, with further references, see Roig Lanzillotta, Punishment 141-52.

11 Nasafī, Tabșira ii, 771-2. For further references on retaliatory punishment in Islamic eschatology, see Lange, Justice 147 n. 64.

12 Plato, Gorgias 525b-d; see also idem, Phaedo 114a-b; idem, Republic 615a-e.

13 Bauckham, Fate 147.

14 Daley, Hope 104: "And as we believe that the devil and all apostates and impious sinners, who say in their heart, 'There is no God,' will undergo eternal punishments, so we think that those who are sinners - even impious ones - and yet Christians will have their works tried and purged in fire, but will receive from the judge a moderate sentence, mingled with mercy" (Jerome, In Is 18.66.24).
} 
simultaneously defining the boundaries of the faith group. This doctrine hinged upon bestowing the status of believers on Muslims guilty of grave sins, saving them from eternal hell-fire (in contrast with the Kharijis and Mu'tazilis), although not sparing them all forms of punishment (a position attributed to the "corrupt" Murji'is). ${ }^{15}$

Yet eternal hell-fire in the Sunni tradition is a poorly guarded realm, open to attack on many sides. Here are but four of them. Firstly, some theological arguments could lend themselves to universalist outcomes. This is especially the case for the khulf al-waid (renege on the threat of punishment): if God is free to recant on His threats then why should He not forgive unbelievers, too?16 The Ash'aris are, in fact, forced into conceding this possibility, in theory at least. ${ }^{17}$ These snags caused Maturidi theologians to discard the argument. ${ }^{18}$ Secondly, Islam has kept many of those concepts that precede purgatory in Catholic theology, ${ }^{19}$ but without confining the temporary castigation to a well-defined location. This lack of a clearly-defined purgatory results in a pervious frontier between paradise and hell, offering the damned a chance of escape, the opposite of what took place in the Latin Middle Ages, when the precise location of purgatory acts as the final bolt on the portal of hell, that is to say, the creation of eternal hell-fire. ${ }^{20}$ Alongside the uncertainties as to its whereabouts, there are those regarding the nature of the punishment, which the eschatological traditions illustrate as both purgative and retributive. Thirdly, the idea of intercession, despite its confessional limitations, may have provided an opening for the hope of universal salvation. The Prophet's negotiations with God, which feature so prominently in the narratives of his Ascension (mir $\bar{r} \bar{j}$ ), highlight the oppositeness of promise and threat and raise hopes in the delay or annulment of the sentence.

Lastly, on a wider scale, eternal hell-fire turns out to be a stumbling block for Islam as universalist monotheism. The heated overtones with which the Quran

15 See Hamza, Hell. On the last point, see Nasafì, Tabșira ii, 766 (wa za'amat al-murjìa al-khabïtha anna aḥadan min al-muslimìn lā yu'āqabu 'alā shay' min al-kabä̉ir). On this passage, see Lange, Sins 163 n. 122.

16 Vasalou, Moral 195; see also Vajda, Perpétuité 34-5.

17 Cf. Nasafî, Tabșira ii, 784, 789; Nābulusī, Qawl 217a-218b.

18 See Lange, Sins 22-9. The Ash'ari position did, in fact, encourage theologians in the Ottoman era to accommodate 'universalist' opinions favored by the study and diffusion of Ibn 'Arabī's work. Nābulusī, Qawl, vindicates the legitimacy of this trend, which had been criticized by Harawī, Qawl, 51-53.

19 Cf. Le Goff, Nascita 37-107.

20 Baschet, Justices 554. For a wider discussion, see Pagani, Vane speranze 199-200 (tr. 299-300). 
spells out the eternity of hell suggest that this concept has been the object of inter-religious debate from the beginning and may even have taken on an intra-religious dimension. The gaps in our knowledge of the history of nascent Islam prevent us from establishing whether the Quran's tirades are directed at other religious groups or at "believers"; particularly as we have no way of knowing who the "believers" actually were at this point in religious history. ${ }^{21}$ The Quran censures the Jews for believing that the punishment lasts for a limited number of days; however "Jews" may actually mean "misguided judaizing believers." The Quran's polemic against intercession, in any case, fits in well with the rejection of the Jewish and Christian exclusivist claim that "no one will enter paradise unless he [or she] is a Jew or Christian" (Q 2:111). ${ }^{22}$ On the other side, the idea of fitra (original constitution) and the emphasis on God's mercy and the return of all things unto him do actually share some points with the philosophical concept of apocatastasis.

Leaving the Quran aside, it is clear that the issue of eternal hell is a problem shared by Islam and Christianity alike, two universalist monotheisms that went on to become the official creed of empires, in which ties with political power required religious legitimization of the use of force by the state. The imposition of the dogma of eternal hell (a development that did not arise in either Zoroastrianism or Judaism), in this light, takes on a significant political function. Hannah Arendt, reflecting on the profound political implications of Augustine's espousal of the doctrine of eternal hell, suggested that, through it, "an element of violence was permitted to insinuate itself into both the very structure of Western religious thought and the hierarchy of the Church."23 Arendt compared Augustine's use of the belief in hell to that of Plato, in so far as the Church Father, like the Greek philosopher before him, "understood to what an extent these doctrines could be used as threats in this world, quite apart from their speculative value about a future life." ${ }^{24}$ The Hanbali judge Ibn al-Aqìl (d. 513/1119) is startlingly forthright on the point: whoever plays down the dread of hell, as do Murjiis who deny the punishment of believers and Sufis who claim to be able to quell the Fire, weaken the coercive power of law (siyāsat al-shar ) and are therefore to be condemned as infidels and, if possible,

\footnotetext{
21 Donner, Muhammad, without solving the issue, deserves acknowledgment for having rekindled the debate.

22 Khalil, Salvation 8.

23 Arendt, Authority 132-3.

24 Ibid., 131; see also Eslin, L'Au-delà. In the Neoplatonic tradition, Plato's eschatological myths were overtly read as expressions of the judicial part of his political philosophy. See O'Meara, Platonopolis 107-11.
} 
eliminated by the sword. ${ }^{25}$ As a judge, Ibn al-'Aqil compared his sentencing to death of an Isma'ili to God's sentencing sinners to hell. ${ }^{26}$ Ghazālì's crusade against esoteric and philosophical interpretations of eschatology was prompted by similar concerns for public order. ${ }^{27}$ Both cases illustrate the particularly important role hell played in legitimizing the violence of the state during the Seljuq period. ${ }^{28}$ Ibn al-'Aqil's argument ties the success of the religion to coercion through fear. But this point was highly problematic for Muslim religious scholars, who shared in many respects the deep ambivalence of their Christian counterparts towards the political sphere. ${ }^{29}$ Moreover, it can be argued that the failure to recognize the humanity of one's opponent, which the recourse to violence entails, ${ }^{30}$ jeopardizes the very foundations of the universal mission of a religion that claims to be destined for all men created equally according to the fitra or in the likeness of God. ${ }^{31}$

As a consequence of these various factors, both in Islam and in Christianity, critiques of the eternity of hell follow on the heels of the dogma of eternal hell. Despite official condemnation, they badger and hound it from within, so hell is not solely vulnerable to attacks from without by dualists and zindiqs (free-thinkers), ${ }^{32}$ but also from religious key figures in the community, even though the orthodoxy of these figures may be contentious. In fact, it was primarily the mystics, both Muslim and Christian, who voiced criticism of hell from within. It is in the area of mysticism that cross-pollination between Islam and Christianity appears most clearly. ${ }^{33}$

Isaac of Nineveh (d. ca. 8o/70o), who lived in Iraq in the first Islamic century, criticised the eternity of hell with arguments that combined the theological-philosophical theory of apocatastasis and the eschatological hope of the "tender-hearted." His case is particularly significant because it proves that this trend survived in eastern Christianity, despite official hostility, especially

25 Ibn al-Jawzī, Talbīs 82, 332, 335 .

26 Griffel, Apostasie 282.

27 See Lange, Throne $144-5$.

28 See on the whole issue, Lange, Justice, esp. 47, 147, 239.

29 See Crone, No compulsion 167-9.

30 See Brague, Philosophies 198-216.

31 The interpretation of the notion of fitra is the basic problem behind the controversy over the salvation of babies born to polytheists and the related debate on the legitimacy of their killing in jihād. See Gobillot, Conception 26-45, 83-4.

32 See Crone, Abū Sa'̄ì 101-3; Urvoy, Penseurs 114, 125.

33 For further parallels between the arguments made by Muslim, Jewish and Christian theologians, see van Ess, Das begrenzte Paradies 111-112. 
in monastic spheres and more specifically in Syriac monasticism. ${ }^{34}$ Isaac of Nineveh's tract on hell was translated into Arabic by the monk Ḥanūn b. Yūhannā Ibn al-Ṣalt (d. after 286/90o) at the end of the third/ninth century, and the spread of thinking similar to his own among Persian Christians in the following century is reported by 'Abd al-Jabbār (d. 415/1025). ${ }^{35}$ Both Isaac's name and ideas were known to al-Shahrastānī (d. 548/1153), who calls him Mār Ishāa (Saint Isaac) and sums up his stance on hell in terms that would have sounded familiar to the Muslim supporters of salvation for all: the universality of mercy, the incompatibility of divine benevolence with the eternity of castigation, the possibility of khulf al-waid. ${ }^{36}$

Ibn al-Ṣalt opens his translation with a very interesting remark: at his time the works of Isaac were kept and studied yet their diffusion was discouraged. The translator, nevertheless, appears to feel that making them more accessible was useful. It has been suggested that his aim was to make use of them in the debate with Islam. ${ }^{37}$ This remark by Ibn al-Șalt illustrates the delicate position that the criticism of eternal hell occupied when put forward by a saint within the context of a religion that officially condemned this attitude. Although questionable and marginal, this opinion would continue to be transmitted privately and informally, and could be tolerated as long as it remained an intellectual hypothesis and an aspiration, without turning into a dogma, that is to say "heresy."

34 On Isaac of Nineveh's eschatology see Chialà, Ascesi 263-282. In 170/786-7, Origenism was condemned anew by Timothy I (d. 207/823), the Nestorian patriarch of Baghdad; the initiative was related to the doctrine's survival among the monks. See Berti, Grazia, 223. There is evidence that these ideas were still circulating in the 7 th/13th century. See Reinink, Origenism 241, 249. A further witness to the universalist tendencies in Syriac monasticism can be located in an early eight century dispute between a monk and a Muslim amir. To the latter's question: "Are the sons of Hagar going to enter the Kingdom or not?", the monk answers: "If there is a man who has good deeds, he will live in grace, in abodes far removed from torment. However, he will think of himself as a hired man and not as a son." See Griffith, Disputing 49-50.

35 Cf. Reynolds, Medieval 223-5. Reynolds says that to imagine here an influence from Origen would be "farfetched and speculative," but he seems overcautious in view of the circumstantial evidence.

36 Shahrastānī, Milal ii, $28-9$ (ch. on the Melkites). Another possible clue suggesting that Isaac was known to Muslims can be found in the catalogue of Christian sects compiled by the Mu'tazili theologian al-Nāshi' al-Akbar (d. 293/906), which mentions among these the "Isaacites" (Ishāqiyya), who can presumably be identified with the followers of Isaac of Nineveh. See Thomas, Christian doctrines, 53 .

37 Chialà, Ascesi 6o-3, 334-5; Swanson, Ibn al-Ṣalt 161. 
Tolerance shown towards such doctrines obviously depended on whether or not there was a willingness to allow for mystical approaches to religion within the community. In Islam, as we know, the delicate balance between mystics and theologians was upset whenever the formers' more dubious 'secret doctrines' surfaced in the public domain through writings or preaching.

Among the Muslim mystics of the third/ninth and fourth/tenth centuries, the case of al-Hakìm al-Tirmidhī (d. between 295/905 and 300/910) deserves greater attention. Al-Tirmidhī, who was temporarily banished from his hometown, Tirmidh, ${ }^{38}$ for having "spoken of love," was particularly concerned with the notion of fitra and the question of the salvation of infants, and his description of the purifying function of hell-fire shares some features with the Christian doctrine of apocatastasis. ${ }^{39}$ The most open testimony to the criticism of hell in Sufism at this time are the ecstatic utterances (shațahāt) attributed to al-Bisțāmī (d. 261/874) and al-Shiblī (d. 334/945): they voice the universal mercy characteristic of the friends of God, with overtones of a protest against the doctrine which restricts the intercession $\left(\operatorname{shafa}_{\bar{a}}^{\mathrm{c}} a\right)$ of the Prophet to his own community. ${ }^{40}$ Insolence that, as we have seen, was harshly checked by Ibn al-'Aqīl.

The spread of this defiant criticism of hell is one of the issues that brought Sufism and the political and religious orthodoxy into open conflict. In the case of the mystics, their criticism of eschatology was quite distinct from that of the philosophers ( falāsifa) as it sprang from a religious impetus of charity and was accompanied by a claim to sainthood. Moreover, the allegorical interpretation of hell typical of the philosophical tradition does not necessarily question the usefulness of its political function for the masses.

This background information demonstrates that Ibn 'Arabī, illustrating comprehensively in writing his own "compassionate" interpretation of eschatology, performed an act of great moment, perfectly in line with his very high conception of his own function as "seal of the saints" (khatam al-awliy $\vec{a}$ ). Indeed, the issue of the cessation of infernal castigation occupies a key role in Ibn 'Arabì as it is the destination of his line of thinking on the encompassing universality of divine mercy ('umüm and shumūl al-rahma). For him, this

38 A city in which Jahm b. Șafwān (d. 128/746) had lived for a long time, leaving there a following. See van Ess, Theologie ii, 494; cf. also ibid., ii, 507-8, for a suggestion that there were possible affinities between Jahmites and local Sufis. An awareness of Jahmite ideas may be detected in al-Tirmidhi’s theology. See Radtke, Theosophie 163-4.

$40 \quad$ Ibn al-Jawzī, Talbiss 332, 335. See also Hatem, Amour 54, 64, 79. On the case of al-Hallāj (d. 309/922), see ibid., 85; Massignon Passion iii, 217; Addas, Victoire 76-7. 
thread running through his work is not merely a theory deriving from his metaphysical vision but "glad tidings" (bushrā) which he himself brings to humankind. ${ }^{41}$ Ibn 'Arabī shares this expectancy with the ecstatic mystics who came before him, yet differs from them because he does not challenge the Shari'a and the Sunna, but claims to be their inspired interpreter. Universal salvation is neither against the Law nor in competition with Muhammad's intercession, rather, it is the deepest meaning of the universality of the Shari'a and the telos of Muhammad's mission. ${ }^{42}$ This meaning and this telos are as yet unaccomplished, and the saint, who is both commentator and intercessor, provides decisive aid in bringing them about. For this very reason the "seal of the saints" considers himself to be the "heir of Muhammad" and not an ecstatic mystic or the maître à penser of a particular school.

The link between universal salvation and the doctrine of sainthood, as well as the implicit claims to authority, could not have escaped Ibn Taymiyya, who channelled much of his dialectic skill into dismantling Ibn 'Arabì's hagiology. It may even have provided the Hanbali scholar and his disciple Ibn al-Qayyim with a cue for radically rethinking eschatology, thus safeguarding the universalist tendency of Islam without following Ibn 'Arabì in his more dangerous ideas.

\section{Ibn al-Qayyim's Reform of Political Hell}

Ibn al-Qayyim resolutely disentangles the disorderly and contradictory mesh of the Sunni hell, putting forward a coherent and rational reform within the framework of a strict theodicy. ${ }^{43}$ Castigation, in so far as it entails infliction of pain, constitutes an evil; however, within the cosmos created and governed by God, evil, in itself, cannot exist. It is therefore a relative evil justified by a wise purpose (hikma). It is not retributive, as retribution brings nothing of benefit to either the evildoer or God, who has no need for revenge. It has, hence, a purifying function and as such cannot but have a limited duration. This is because once the sinner is healed and reformed the castigation has fulfilled its

\footnotetext{
41 Ibn 'Arabī, Futūḥāt ii, 206-7.

42 Cf. Chodkiewicz, Océan 66; idem, Banner 51; Addas, Victoire 57-79. To my knowledge, the latter study is the most exhaustive on the concept of apocatastasis in Ibn 'Arabī, with special attention to the soteriological role of the Prophet, which will not be covered in this article. Manāìì, 'Aqīda; Khalil, Salvation 92-102; Ajhar, Su’āl 257-69. See also Abrahamov, Creation.
} 
purpose. Even when this requires a long lapse of time, the punishment restores man's original constitution ( fitra) to its primary state much in the same way as drastic medical treatments, such as cauterization or amputation "remove alien matter that has accidentally corrupted the sound nature (tabi'a mustaqima) of an invalid". ${ }^{44}$ By way of its beneficial, although painful, character, punishment is an expression of mercy, an attribute of the divine essence that prevails over the incidental attribute of wrath.

This therapeutic model of punishment ${ }^{45}$ is located inside a providentialist outlook in which evil lacks an ontological standing of its own and will, ultimately, be completely eliminated, so much so that even Iblīs will probably be redeemed. As Hoover remarks “[Ibn al-Qayyim's] aim is apologetic. He is trying to explain why God creates evil and to defend God's wise purpose against detractors." ${ }^{46}$ One is tempted to add that Ibn al-Qayyim is also a political writer who defends state power; not an arbitrary power that indifferently shows clemency or inflicts punishment but a rational and wise power. ${ }^{47}$

Ibn al-Qayyim employs legal terms to describe the punishment of hell, associating it with the hudüd (divinely ordained punishments), and by doing so setting it within the framework of public criminal law, in which the hudüd are generally characterized as "rights of God" (ḥuqūq Allāh):

God does not quench his thirst for revenge by punishing His servants, as does he who has suffered wrongdoing when he takes revenge on the offender. He does not harrow His servant with this purpose, but with the aim of redeeming him and because of His mercy towards him. His punishment is, in fact, a benefit (mașlaha) to him, despite the infliction of great pain; likewise the application of the hudūd in this world is of benefit to whoever is subjected to them. ${ }^{48}$

44 Ibn al-Qayyim, Hāà̄ 370. The same analogy is found in Ghazālī, Maqșad 68. See also Khalil, Salvation $46-7$. It was already used by Neoplatonists. See O'Meara, Platonopolis 109.

45 On the importance of this model see Hoover, God's wise purposes 115; idem, Islamic Universalism 189; Khalil, Salvation 97.

46 Hoover, God's Wise Purposes 127.

47 Instead, al-Nasafī, in response to a Qadarī objection, compares God to the ruler, who for the same offence may grant a pardon or impose a punishment. See Nasafi, Tabșira ii, 767 , 776. On the correlation between the arbitrariness of Seljuk rulers and that of the Ash'ari God, see Lange, Throne 141 .

48 Ibn al-Qayyim, Hād̄̄ 369 . 
The analogy of the hudūd appears to be even more effective than that of medicine in describing infernal castigation. Indeed, Ibn al-Qayyim foresees the objection that the treatment that causes the sick person suffering, differently from the torment of the damned, is not referred to as "punishment" as the physician cares for his patient and feels no anger towards him. This is true, replies Ibn al-Qayyim, "but this does not mean that the punishment cannot be mercy towards them, as the hudūd in this world are simultaneously punishment, mercy and purgation." 49

In one of his legal works, Ibn al-Qayyim explains that the hudüd have a purifying and reforming function: in the case of capital punishment, these penalties rehabilitate the sinner's soul, though not his body, because they exempt him from hell..$^{50}$ Like the hudūd, infernal castigation, by virtue of its being gainful, is inevitable, even though mercy is dearer to God than punishment, ${ }^{51}$ and even though the suffering experienced by those who are punished evokes pity in others. ${ }^{52}$ Indeed, "tribulation is mercy" (al-ibtilä rahma), and for this reason, God answers those who pray for mercy for those who suffer great tribulation: "How can I be merciful towards him by depriving him of the very same thing through which I show him mercy?" (kayfa arhamuhu min shay' arhamuhu bihi).53 The hikma and the mașlaḥa (utility, common good) justifying the punishments and the sufferings borne in this world and the next are one and the same: following careful contemplation one can discover the perfect correspondence (tanāsub) and harmony (tawäfuq) between earthly and otherworldly rewards and punishments, all similarly serving the purpose of healing and purification. ${ }^{54}$

In conclusion, the temporary hell, which is described by Ibn al-Qayyim either as a hospital (māristān $)^{55}$ or as a prison, is a political hell: a place where violence is employed in the name of the common good, within the limits of reason. Hence, unlike the mystics' protests against hell censured by Ibn al-'Aqil, Ibn al-Qayyim's 'reform' of hell does not undermine the coercive power of the

49 Ibid., 371. See also Ibn al-Qayyim, Shifä' 692-4, 698, 720-1.

50 Ibn al-Qayyim, I'lām i, 97; ii, 72-3; iii, $15-6$. On the theory that hadd crimes are expiated by earthly punishments, see Lange, Sins 148 n. 29, 151 n. 59.

$5^{1} \quad$ Khalil, Salvation 96.

52 Cf. Ibn Taymiyya's argument for the divine mercy concealed in the enforcement of hudūd: the father would spoil his son if he refrained from punishing him as his tender mother would have it. See Ibn Taymiyya, Siyāsa 79; cf. also Ghazālī, Maqșad 68.

53 Ibn al-Qayyim, Hiādī 376.

54 Ibid., 369; see also ibid., 379. On the correspondence between worldly and otherworldly legal rules see also idem, I'lām, iii, 115 .

Ibn al-Qayyim, Shifä’ 692. 
law (siyāsat al-shar ), but instead rationalizes it. In this regard, Ibn al-Qayyim's understanding of justice in the netherworld, while reminiscent of ancient precedents, ${ }^{56}$ anticipates the critique of eternal hell that would affirm itself in Modern Europe along with the adoption of a penal theory founded on the ideas of reform and deterrence rather than retribution. ${ }^{57}$ It hardly comes as a surprise, therefore, that Ibn al-Qayyim has been favourably received among Islamic modernists. ${ }^{58}$

\section{The Hell of Wrath and the Hell of Mercy}

Ibn 'Arabỉ's conception of hell is much less easy to circumscribe than that of Ibn al-Qayyim. If we approach it from the angle of its legal implications, we are confronted with two major questions. The first concerns the relationship between the legal function of hell and the other roles it fulfils through its continued existence. The second concerns the model of justice to which its legal function is related. We will deal with the first question in this section, and with the second in the next one.

According to Ibn 'Arabī, once a term of infernal punishment has come to an end, hell ceases to be "painful," although it does not cease to exist altogether. As is done in the mainstream Sunni tradition, Ibn 'Arabī makes a distinction between sinful believers whose stay in hell is only temporary and "the people of the Fire, those who are its inhabitants" (ahl al-nār alladhina hum ahluhā), and will stay there eternally. However, according to him, the eternity of the stay does not necessarily imply that the punishment ('adhāb) will be eternal, too. ${ }^{59}$

The term 'adhāb raises some issues as Ibn 'Arabī uses it both in its primary meaning of "castigation," as in the Quran, and also in the broader sense of "suffering." Thus, certain passages may lead us to think that the cessation of 'adhāb is solely the end of suffering but not of the punishment in the legal sense. As

56 On otherworldly punishment as therapy in Plato and Origen, see, respectively, McKenzie Plato 177-8, 184, 187, 203; Daley, Hope 57. Cf. also Augustine, De Civ. Dei 21.13. For the sake of coherence, Neoplatonists adhering to Plato's reformative conception of justice rejected his idea that "incurable" souls will suffer eternal punishment. See O'Meara, Platonopolis 107-111.

Rowell, Hell and the Victorians 13. See also Walker, Decline of hell 29-32.

$5^{8}$ Manāīì, 'Aqīda 93, 100, 121; Khalil, Salvation 110-35.

59 Chittick, Death 77; Chodkiewicz, Océan 67; Addas, Victoire 64; Manāīì, 'Aqīda 1o6; Khalil, Salvation $62-3$. I leave aside here the question of what kind of people actually qualifies for eternal hell, which is in turn related to Ibn 'Arabī's definition of infidelity. See Chittick, Religious diversity 152-5; Khalil, Salvation 55-62; Gril, Pharaon. 
an example, describing the way in which the ahl al-när ("the people of the Fire") lose their sensitivity to the pain (al-ihssās bi-l-älām) of burning, Ibn 'Arabī compares their situation to that of sinful believers who, according to a hadith, God lets die (amātahum Allāhu fiha imätatan) so as to spare them the suffering of their temporary stay in hell. ${ }^{60}$ In this case, the absence of pain can be considered simply as an easing, but not a discontinuation, of the punishment.

However, further passages clarify that, for Ibn 'Arabī, what draws to a close is the punishment in its legal sense: "When the fixed penalty (hadd) against ahl al-nār comes to its end, they dwell in hell-fire because they are suited to it (bi-l-ahliyya) and not as recompense (bi-l-jazā')."61 Indeed, the duration of the castigation in hell stands as a "proportional recompense" ( $j a z \bar{a}^{\prime}$ wifāq, Q 78:26), corresponding exactly to what is merited (istihqāq) on account of one's evil deeds in this world. It is, therefore, limited, insomuch as limited sin could not warrant unlimited punishment. ${ }^{62}$ At the same time, while in the Quran the expression jaz $\bar{a}^{3} w i f a \bar{q}$ (proportional recompense) appears solely in reference to infernal punishment, Ibn 'Arabī also applies it to the reward that the faithful receive through merit, in a special paradise called the "paradise of deeds" (jannat al-a'māl). In the case also of the blessed, the reward earned through deeds is bestowed over a limited period of time..$^{63}$

Thus, limited duration pertains to the function of the two abodes in so far as they are loci of reward and punishment. Once the spell is over, both the eternal extension of the pleasures of paradise and the transformation

6o Ibn 'Arabī, Futūḥāt i, 303. The hadith is found in Muslim, Șaḥịh, k. al-īmān 82 (bāb ithbāt al-shafā'a wa ikhräj al-muwahhidīn min al-när). It specifies that experiencing death in hell is a special favour accorded to sinful believers. This restriction is mentioned elsewhere also by Ibn 'Arabī. See Futūhāàt ii, 161; Sha'rānī, Yawāqüt ii, 469. In his commentary on Muslim, al-Nawawi says that the death accorded to the sinful believers is "real" (hädhihi al-imāta imāta haqììyya), and that it makes them lose their sensibility after they have suffered a punishment proportional ('alā qadr) to their sins. See Nawawī, Sharh iii, 38 . According to Qurțubī, "death" can be taken here either literally (mawta haquíqiyya) or as a metaphor for a state of unconsciousness. He further explains that even if God does not torment these sinners (wa-in lam yu'adhdhibhum), their stay in hell is a punishment ('uqūba), in the same way as serving a prison sentence without being put in chains. See Qurțubī, Tadhkira 769-71 (bāb man dakhala al-när min al-muwahḥidīn māta wa-ḥtaraqa thumma yakhrujūna bi-l-shafā'a).

61 Ḥakīm, Mújam 1089, quoting Ibn 'Arabī, Futūhạàt iv, 120.

62 Chittick, Death 77.

63 Ḥakīm, Mújam 288; 1021-2. Cf. also Ibn 'Arabī, Futūhạt ii, 212-3, transl. in Addas, Victoire, 65-6: once the spell of reward and punishment is over, all are "rewarded" by divine mercy by virtue of their original disposition to love and serve God. 
of infernal misery into bliss depend on divine grace (minna), as opposed to deserts (istihqua $q$ ). Indeed, both perpetual reward and perpetual punishment are beyond equity. Going beyond equity in reward is generosity $(f a d l)$, while it would be blameworthy in the case of punishment. ${ }^{64}$ Once the period of reward or punishment has ended, divine mercy embraces the people of the two abodes, notwithstanding the fact these are separate and that different forms of bliss (naim) are found in each.

Although some critics, from the time of Ibn Taymiyya onwards, have drawn parallels between Ibn 'Arabī and the Jahmiyya, ${ }^{65}$ this idea does not imply the annihilation of paradise and hell, rather, it amounts to a downgrading of the retributive concept of the afterlife in a spirit akin to Rābi'a al-'Adawiyya (d. 185/801), who wished to burn paradise and put out hell as places of reward and punishment. ${ }^{66}$ So, despite having fulfilled its legal function, hell continues onto eternity.

The reason for hell's eternity is both theological and anthropological. Theologically, it fulfils the economy of the Divine Names: hell is the eternal manifestation of wrath, even when its hukm (rule) comes to an end, in contrast to that of divine satisfaction (yantahi hukmuhu wa-là yantahi hukm al-ridāa). ${ }^{67}$ That Divine Names of wrath manifest themselves without exercising their hukm is a key concept that deserves attention. In linguistic terms, this means that the names lose their referential, but not their significative function. ${ }^{68}$ In legal terms, this means that penal law ceases to be operative, without being declared invalid. Ibn 'Arabī compares God's giving preponderance (tarjīh) to mercy over wrath to the choice of the judge between two equally legitimate decisions: "When God weighs mercy against wrath, mercy preponderates and is heavier, and wrath is lifted; that something is lifted has no other meaning that it ceases to be in operation; therefore, in the outcome, divine wrath has

\footnotetext{
64 Cf. Ibn 'Arabī, Futūḥāt iv, 171.

65 Cf. van Ess, Theologie ii, 508. Yet, in a way that recalls an opinion attributed to the Jahmiyya, Ibn 'Arabī says that, despite not being believers, those who know the oneness of God are not among the permanent inhabitants of hell. See Ibn 'Arabī, Futūhāa ti, 314, and cf. van Ess, Theologie ii, 503; Ibn al-Jawzī, Talbīs 22.

66 A possible parallel in Syriac mysticism can be found in Stephen Bar Sudaili (c. 480-c. 543), who posits an end to both reward and punishment, after which all will be enveloped in divine mercy. See Guillaumont, Conférence 370; Daley, Hope 176-8. Cf. van Ess, Theologie iv, 548; idem, Das begrenzte Paradies 111.

67 Ibn 'Arabī, Futūhạat iii, 383. Cf. Chittick, Religious diversity 115-6; idem, Death 79.

68 Cf. Ajhar, Su'äl 193.
} 
no enforcement power." ${ }^{69}$ Notwithstanding this, the Divine Names of wrath do not lose the "right" to be fulfilled, which is implemented through the manifestation of their properties in the imaginative realm. ${ }^{70}$ In other words, the outward show of punishment is eternal in its exemplarity. It is a pure spectacle, hiding the reality of divine mercy. ${ }^{71}$

Anthropologically, eternal hell, as a "veil" or "separation" (hijāb) from God, is made necessary by the inability of certain natures to sustain the vision of God and bear the climate of paradise. ${ }^{72}$ The hija $b$, being deprivation, is a form of suffering, but as hell is not punishment in the legal sense of the term, it does not qualify as a poena damni, but is the inevitable consequence of a lack of knowledge. ${ }^{73}$ This is close to Ibn Sīnā's intellectualist conception, where imperfect souls cannot aspire to absolute beatitude, but also to the mystical vision of Emanuel Swedenborg, where the souls that lack charity

were seized by such anguish of heart from the approach of heavenly heat, which is the love in which angels are, and from the influx of heavenly light, which is Divine truth, that they perceived in themselves infernal torment instead of heavenly joy, and being struck with dismay, they cast themselves down headlong. ${ }^{74}$

69 Ibn 'Arabī, Futūḥāt iii, 176: fa-lammā wāzana Allāh bayna al-raḥma wa l-ghaḍab rajahat al-rahmma wa-thaqulat wa-irtafa'a al-ghaḍab al-ilāhī wa lā ma'nā li-irtifā' al-shay' illā zawāl hukmihi; fa-lam yabqa min al-ghadab al-ilāhi hukm fi l-ma'äl. It is interesting to note that the notion that a law can lose its binding force without being rendered null by abrogation plays an important role in Ibn 'Arabỉ's view of the relationship of Islam with Judaism and Christianity. See Chittick, Religious diversity 125 .

70 Ibn 'Arabī, Futūhāt iii, 119: fa-ḥaythu zahara ḥukm al-Muntaqim [...] fa-qad istawfā haqquhu bi-zuhür hukmihi. For a translation, see Chittick, Religious diversity 115.

71 Cf. Ibn 'Arabì's interpretation of the "wall" dividing the Garden from the Fire in Q 57:13. Chittick, Religious diversity 117-8.

72 Chittick, Death 79-80; idem, Religious diversity 117-8.

73 Cf. 'Afîfî's comment in Ibn 'Arabī, Fușūṣ ii, 96. For the same reason, the "paradise of the knower" ( jannat al-ärif) is different from that of the believer. See ibid., ii, 90.

74 Swedenborg, Heaven and hell 340. Cf. Ibn 'Arabī, Futūhāt iv, 14: "And if they were resurrected from their graves in the constitution of their own abode and were given a choice between the Garden and the Fire, they would choose the Fire, just as a fish chooses water and flees from the air through which the inhabitants of the earth have life" (tr. Chittick, Religious Diversity 118). For the comparison with Swedenborg, see Corbin, Imagination 260, 270 . 
Ibn 'Arabī imagines 'infernal pleasure' both as the cessation of pain and as an actual "independent bliss" (na ìm mustaqill) alongside it. ${ }^{75}$ He remarks on a number of occasions that 'adhāb comes from the same root as 'udhüba (sweetness), and this shows that the torment of hell-fire will turn into pleasure. ${ }^{76}$ Before him al-Zamakhsharī (d. 538/1144) had dwelt on the link between the two meanings, putting forward an explanation based on the meaning of 'adhāb as deterrent penalty: as freshwater ('adhb) quenches thirst, the deterrent penalty ('adhāb) quells the desire to commit a crime. ${ }^{77}$ The double meaning of the root ${ }^{c}-d h-b$, exploited in erotic poetry (being tortured by your beloved is sweet), is further expanded in the mysticism of amorous martyrdom. This is the case of Hallāj, who calls forth and pursues "la suave extase dans le supplice" (maldhüdh wajdī bi-l-'adhäb). ${ }^{78}$ The idea seems even to have captivated Ibn al-Qayyim, who states that the punishment turns into bliss (inqalaba na'iman) for those who accept it as rightful and healing. ${ }^{79}$

However, Ibn 'Arabī is far from extolling suffering. Naìm in his hell has nothing sublime about it: in contrast with ' $a d h \bar{a} b$, it is whatever is appropriate (muläim) to the "nature" $(t a b)$ or "temperament" (mizāj) of each man. ${ }^{80}$ 'Adhāb thus becomes sweet when it is no longer against nature. The ahl al-nār relish hell like natives love their homeland (mawtin) and are drawn to it like iron to a magnet. ${ }^{81}$

Occasionally, Ibn 'Arabī appears to emphasize the redeeming properties of the ahl al-nār's happiness, as when he compares them to Abraham, who found "coolness and safety" (bardan wa-saläman) in the furnace. ${ }^{82}$ Elsewhere their pleasure is described as relish in wretchedness, quite simply "natural perversion": 83 something more akin to Fourier's utopia, where everyone follows his inclinations, than to the "virtuous city" of the faläsifa. To all appearances, given Ibn 'Arabï's definition of the notions of pleasure and pain, there is a variety of natural pleasures which, though being peculiar, should not be

75 Ibn 'Arabī, Fuṣūṣ i, 114. Cf. Addas, Victoire 74.

76 Ibn 'Arabī, Fuṣūṣ i, 94; idem, Futūhāat ii, 207. Cf. Chodkiewicz, Océan 66; Khalil, Salvation 66.

77 Zamakhsharī, Kashshāf (ad Q 2:7). See also Lane, Lexicon v, 1982.

78 Hatem, Amour 113 .

79 Ibn al-Qayyim, Hiādī 373 .

8o Ḥakim, Mujam 786-8; Chittick, Death 79-80; idem, Religious diversity 117-8.

81 Ḥakìm, Mújam 1089, 1091.

82 Ibn 'Arabī, Fuṣūṣ i, 169. Cf. Q 21:69.

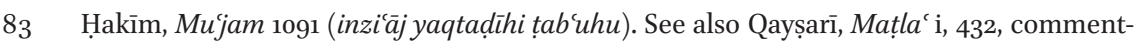
ing on Fușuṣ i, 94: "bliss for corrupt (khabìtha) souls comes only from vile things, like a dung beetle relishes filth and cannot abide good things." 
considered as diseases. ${ }^{84}$ Such an outlook is foreign to Ibn al-Qayyim for whom medicine restores us to "sound nature" (țabīa mustaqima) in the same way as infernal punishment restores our "original constitution" ( fitra) to health. ${ }^{85}$ But the natural aversion of certain souls from paradise is problematic also in connection with what Ibn 'Arabī himself says of the fitra. In fact, the fitra is for him a key argument in favour of universal salvation, in so far as he considers it as the original and unalterable disposition to know God, which is common to every human being. ${ }^{86}$ Thanks to this, hell cannot be the "home" (mawțin) of the rational soul, and if it were to alight there the flame would be smothered. ${ }^{87}$ But fitra has for Ibn 'Arabī a great variety of meanings. ${ }^{88}$ So, while adhering to a universalist conception of fitra, he does not dismiss altogether the alternative interpretation of this notion which prevailed in Sunni tradition, and according to which God gives men different "original constitutions" ordaining them ab aeterno either to hell or paradise. ${ }^{89}$ However, Ibn 'Arabī curbs this idea from its predestinarian outlook towards a universal determinism: God's decree does not damn people but only establishes their dwelling-place. ${ }^{90}$

We have here a major difficulty: if the "people of the Fire" are not restored to the fullness of the original disposition, because it was pre-determined that their individual natures would not attain the felicity of human perfection, in what sense can we say that Ibn 'Arabì maintains "universal salvation"? In order to answer this question, we have to go back to Ibn 'Arabī's original use of the theological distinction between God's ontological and moral will, or His "creation" and His "command."91 The paradoxes of determinism are a recurring motif in Ibn 'Arabī's writings. The real meaning of the "decree" (qadar) is a "secret" that revelation jealously veils, ${ }^{92}$ because it betrays the fact that

84 Cf. the debate on the possibility of sodomy in paradise. See Lange, Justice 211.

85 Cf. above, n. 44.

86 See Addas, Victoire 64-6. Cf. also Chittick, Religious diversity $5^{1-2 .}$

87 Ḥakīm, Mu'jam 296, quoting Ibn 'Arabī, Futūhāat iii, 36o. On the dignity (sharaf) of the rational soul, see 'Abd al-Qādir, Mawāqif ii, 932, 936, 941.

88 See Gobillot, Conception 60-1.

89 See ibid., $32-45,46-5^{1}$ (on the theological debate), and $62-5$ (on the rejection of the predestinarian interpretation by Ibn Taymiyya and Ibn al-Qayyim). Cf. Ibn 'Arabī, Futūhạat ii, 330, where Ibn 'Arabī says that certain rational souls are not originally disposed to knowledge of God (lam tufțar 'alā al-ilm bi-llāh ), and were destined to hell since the pre-eternal Covenant (cf. Q 7:172). See also 'Abd al-Qādir, Mawāqifii, 935.

90 Cf. Ibn 'Arabī, Futūhāt iii, 76; Chittick, Death 77.

91 For references to the use of these concepts before Ibn 'Arabī, see Hoover, Theodicy 128-9; Ajhar, Su'āl 227-8.

92 Cf. Ibn 'Arabī, Fuṣūṣ i, 131; see also ibid., 109-10. 
disobedience to God's "command" is morally evil but ontologically good. God's creative mercy lets everything subsist conforming with its "fixed entities" (a'yān thäbita), ${ }^{93}$ the concrete determinations of singular beings that since pre-eternity are established as potentialities in God's knowledge, and which, in themselves, are neither good nor evil, but "indifferent". God's "command," instead, is what confers their legal-moral qualifications to the actualized manifestations of the "fixed entities," through the revelation of the Law. ${ }^{94}$ The injunctions and prohibitions of the Law can be disobeyed: they are a verbal imperative through which God commands what He lacks the power to impose, unlike God's creative imperative, the kun, which is necessarily fulfilled. ${ }^{95}$ Hell as a temporary legal institution where moral evil is punished is under the sway of God's wrath, but as an eternal dwelling-place it is the object of God's creative will and mercy, which encompasses and "precedes" wrath.

Precisely this aspect of Ibn 'Arabī's eschatology is the target of Ibn Taymiyya's criticism: according to the latter, the emphasis on God's ontological mercy leads to disregard His moral will, and actually paves the way for the antinomian tendencies of some of Ibn 'Arabì's followers. ${ }^{96}$ Ibn 'Arabì's distinction between the two dimensions of hell, the legal and the existential, is obviously incompatible with the view held by the majority, for whom eternal hell is the fulfilment of an irrevocable sentence against unbelievers. Yet it is also incompatible with Ibn al-Qayyim's hell as this too, as long as it lasts, has a penal function. Ibn al-Qayyim is without doubt unfair when he states that according to Ibn 'Arabī "nobody at all is punished in hell" ('indahu lāyu'adhdhabu bihāahad așlan), ${ }^{97}$ as he does not take account either of the temporary punishment or of the deprivation of the vision of God that Ibn 'Arabi foresees. Yet the accusation is not entirely unfounded in so far as the driving force behind Ibn 'Arabī's hermeneutics is the desire to dispense with punishment altogether:

We have experienced in ourselves and in those God made benevolent by nature that they have compassion for all men, to such an extent that if God were to give them authority over creation they would erase punishment completely from the world. ${ }^{98}$

93 On this translation, see Chittick, Cosmology xxxviii.

94 Cf. Chittick, Religious diversity 47-8.

95 Cf. Ajhar, Su'āl 186.

96 Knysh, Ibn 'Arabi 92; Hoover, Theodicy 110, 125, 130; Ajhar, Su'āl 227, 256.

97 Ibn al-Qayyim, Hāāī 353. See Manāīi, 'Aqīda 93, 127-9; Khalil, Salvation 93.

98 Ibn 'Arabī, Futūhāat iii, 25. For a translation, see Addas, Victoire 63. 
Ibn 'Arabī's desire, however, is reined in by adab, the proper manner of behaving with God, which is a consequence of the receptivity to His Word. ${ }^{99}$

As we will see in the next section, Ibn 'Arabì considers the end of punishment not only as the necessary consequence of God's ontological mercy, but also as the deepest intention of His revealed Law. This intention, however, can only be fulfilled if man understands it and freely chooses to put it into practice. In this sense, God's moral command plays a key role in Ibn 'Arabì's scheme of salvation, a scheme where man is an active participant and not only the passive recipient of mercy. But salvation, which is "universal" from the point of view of God's ontological mercy, can only be individual in so far as it results from man's answer to God's personal revelation.

We have seen that Ibn al-Qayyim plainly affirms the "correspondence" between earthly and otherworldly punishment in so far as both aim at the restoration of the common good. Ișlāh, which has the meaning of "making wholesome,"100 or "restoration," and is thus very close to "apocatastasis," is also a key-term of Ibn 'Arabì's eschatology. The latter, however, uses it in reference to two different processes: reparation in the afterlife is brought about both by a purifying and inescapable punishment, and by reconciliation and forgiveness. We will now attempt to show how these two different processes are related to each other and to their respective legal counterparts in earthly justice.

As we have seen, hell is the place of proportional recompense ( $\left.j a z \bar{a}^{3} w i f a \bar{q}\right)$, where one can only receive what one deserves. This requital is inevitable as it is literally the product of deeds: one is punished (or rewarded) by the personification of one's actions. It is, therefore, the individual who "creates" and "builds" the hell of punishment (as with the paradise of reward). ${ }^{101}$ Nevertheless, Ibn 'Arabī also describes this penalty as imposed by God, attributing to it a purifying function: "Divine mercy involves punishment solely as a purifying recompense ( $j a z \bar{a}$ l li-l-tathir): were it not for the purification, the punishment would not take place."102 God, like a doctor, makes his patient suffer for his wellbeing:

99 Cf. Gril, Adab.

100 Cf. Chittick, Cosmology 122.

101 Hakīm, Mújam 1089-90; Chittick, Religious diversity 109.

102 Hakīm, Mújam 786-7, quoting from Ibn 'Arabī, Futūhāat iii, 352. On the purifying function of punishment, see also Chittick, Death 78; idem, Religious diversity 109; Feiz, "Qahr" 12. 
The punishment inflicted by God is an act of mercy towards he who undergoes it and a purification, like medicine for an invalid made to suffer by a doctor because of mercy towards him, and not to exact revenge. ${ }^{103}$

While being merciful, punishment is not, however, absolute mercy (rahma): for this reason, when God punishes He is not defined as "the Merciful" (al-rahmān), but as "Lord of the Worlds" (rabb al-älamin). The title rabb ("Lord") encompasses mercy as it implicates reform (iṣläh) and education (tarbiya). ${ }^{104}$ Intrinsic to the rabb is being a

teacher $($ murabbi $)[\ldots]$ : that is he who has the task of reforming the status (ișlāh hâal) of those educated-and education can be a source of pain, as when a person beats his son to teach him a lesson. [...] Similarly, God's hudūd are a lesson to His servants. ${ }^{105}$

Ibn 'Arabī thus justifies punishment in the netherworld by making use of both therapeutic and pedagogic models, as well as legal ones that liken infernal punishment to hudüd. Much like Ibn al-Qayyim after him, he compares the healing properties of the Fire with cauterization and hudūd punishments, which in this world serve as atonements, exempting sinners from punishment in the afterlife. ${ }^{106}$ In this way, Ibn 'Arabì deals with the issue from a theodicean perspective: a relative evil is justified by its wise purpose, in this world as in the next. This approach also safeguards God's transcendence (tanzīh), which literally indicates "exempting" God from all that does not become His perfection. Defending God as a transcendent principle implicates defending the cosmic order and the political order as well.

This perspective does not however decide the issue. Another point of view is that of immanence (tashbih), the idea that there is a "resemblance" between the Creator and the creature, a personal relationship between God and man created in His image. From this angle, Ibn 'Arabì does not speak as a theologian justifying divine castigation but as an advocate-intercessor eager to spare

\footnotetext{
103 Ibn 'Arabī, Futūhạt iv, 256-7.

104 Ibid., i, 308.

105 Ibid., iii, 383 .

106 Ibid., ii, 161: fa-jáala Allāh lahum al-nār [...] dawāà ka-l-kayy bi-l-nār fì l-dunyā [...] idhā ja'alnāhā wiqāya kamā ja'alnā fì l-hudūd al-dunyāwiyya wiqāya min 'adhāb al-ākhira wa-lihādhā hiya kaffārāt ay tasturuhu hādhihi l-ḥudūd 'an 'adhāb al-ākhira. Cf. above, n. 44 and 50. Ibn 'Arabī also defines punishment in the afterlife as "the period in which God's penal laws are operative" (muddat iqāmat al-h̆udūd). See ibid., iii, 346, 383 .
} 
each individual suffering, and for this reason cannot sidestep the issue of pain with a rational line of reasoning. While it is true that many Sufis describe evil as a trial to endure and a chance to reform, ${ }^{107}$ there are notable exceptions, as for example in 'Ațtār's (d. 627/1230) Mușïbat-nāme, where nameless "madmen" and "paupers" argue with God with overtones that recall those of the zindiqs, yet in intimate and personal conversation with Him. ${ }^{108}$ Ibn 'Arabī, for his part, in commenting on the case of Job, approves his complaint (shakwa), countering the position of those Sufis who preach total resignation: "Not to complain to God when you feel an ill contrary to His desire, is to want to resist the divine constraint [...]. Adab, all $a d a b$, is in that complaint addressed to God and to Him alone without losing by that the virtue of patience."109

As we have seen, Ibn 'Arabī is a "well-mannered" intercessor, who does not challenge the Shari'a, but seeks to unfold its potentialities. In this case, like a skilful lawyer, he homes in on the "rights of men" (huqūq al-ibād) rather than the "rights of God" (huqūq Allāh). From this viewpoint, the cornerstone of his discourse on the justice of hell is retaliation (qișasș). The lex talionis is suitable to his purpose precisely because it corresponds to a relational model of justice, where the focus of the law is the harm done to a person, requiring compensation, rather than the transgression of a norm, requiring punishment. ${ }^{110}$ Unlike public penal law, qișass is based on the principle of private prosecution: man has the "right" to forfeit his right to retaliation, ${ }^{111}$ and is even encouraged to do so. The recommendation to pardon is a strong ethical component of Islamic law, which, however, does not abrogate qișās as a law, revoking the right to retaliation or compensation. ${ }^{12}$

Ibn 'Arabī's reflections on qișạs apply equally to this world and to the next. In the chapter of the Fușuṣ on the prophet Jonah, he gives special attention to the following Quranic verse: "The recompense of one evil is an evil like it (wa-jazā̉u sayyia sayyia mithluhā), but whoever pardons and makes reconciliation (așlaha), his reward is with God" (Q 42:40). In his commentary, Ibn 'Arabī emphasizes the fact that God Himself calls retaliation an "evil," "even

\footnotetext{
107 Cf. Hoover, Theodicy 3.

108 See Ritter, Ocean 165-87; idem, Strife.

109 Ibn 'Arabī, Futūhạt iv, 143, (tr. with commentary in Gril, Adab). See also Chittick, Cosmology 121.

110 This fundamental distinction plays a key role in the Mu'tazilite reasoning on otherworldly justice. See Vasalou, Moral 81-2.

111 Peters, Crime 39, 45-6.

112 This interpretation of the lex talionis was also typical of Rabbinic law. Jesus' instruction to turn the other cheek in Matthew 5:39 can be read within this legal framework. See Johnson, Jesus and Moses 100-106.
} 
though it is legal," and that He promises to reward the person who forfeits his right to kill another man, "because he is in His image."113 In the final part of the chapter, Ibn 'Arabì argues against the eternality of hell, clearly establishing an analogy between killing in retaliation and eternal damnation. This analogy is made stronger by the fact that a Quranic verse from the sura of Jonah describes eternal castigation in terms very close to retaliation: "And for those who have earned evil deeds the recompense of an evil deed shall be the like

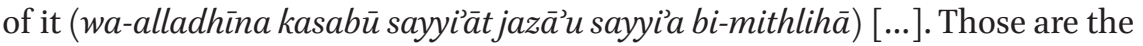
companions of the Fire. They will abide therein eternally" (Q 10:27).

The institution of retaliation has an important place in Ibn 'Arabỉ's reflections about the relationship between law and spirituality. Talionic punishment is an evil for the receiver because suffering is an evil by definition. Yet it is also an evil for he who inflicts it as it negates the makärim al-akhlāq (noble character traits), by virtue of which man becomes like God and achieves his own happiness (sa'äda). Even though retaliation cannot be defined as an "evil" from a legal point of view, according to the Law it is better not to claim it. There is in fact a difference between "good" and "better" rulings of the Law, just as there is a hierarchy of Divine Names, and the noble character traits which correspond to the "most beautiful names" (such as the Generous or the Merciful) can only be acquired by practising the best part of the Law. ${ }^{114}$

Sa a a da is thus attained enacting the Law in its entirety, not only obeying what it enjoins, but also preferring what it recommends. Ibn 'Arabī pays particular attention to the ethical value of not exerting violence when one is given the choice (takhyirr), ${ }_{115}$ which is the case of qișās, but not of hudüd. ${ }^{116}$ The happiness attained by freely choosing what God most desires is clearly distinguished from "natural" happiness. The choice not to repay evil with evil is actually a way to go beyond man's nature $\left(\operatorname{tabi}^{-} a\right)$, the amor sui naturalis that man shares with other living beings and that drives him to seek pleasure-and revenge is a pleasure, too. In this sense, the moral law acts to bridge the abyss

\footnotetext{
113 Ibn 'Arabī, Fușūṣ i, 168 (tr. in Austin, Bezels 209). For further references and commentary, see Pagani, Imago 252; Feiz, Notion 137-8; idem, "Qahr" 7-8; Chittick, Cosmology 122-3, 217.

114 Cf. Ibn 'Arabī, Futūḥāt iv, 171.

115 See Ibn 'Arabī, Fuṣuṣs i, 129-30: The Prophet, when free to choose, opts not to use his powers. The founding principle of the futuwwa is to forego retaliation when one has the strength to enforce it. Cf. Hatem, Amour 87 (quoting from Futūhāt i, 241). On clemency as a political virtue, see Ghazālī, Ihyyä' iii, 179-81 (K. dhamm al-ghadab; b. fadìlat al-'afw wa-l-ịsān).

116 Cf. Ibn 'Arabī, Futūhāàt iv, 46-7.
} 
of one's nature, as the șirāt over hell. ${ }^{117}$ By overcoming the inborn yearnings in their animal soul, humans become truly human; becoming truly human, human beings become divine, actualizing in themselves the image of God. ${ }^{118}$ Spiritual happiness is also distinguished from the common good, because it is not justified by utilitarian considerations, but is an end in itself. Forgiveness grants an immediate spiritual benefit to the one who pardons the offender, to such an extent that "if God removed the veil, and we were to see with our own eyes what great good is there for us in the next world in consequence of that offence, we would say that nobody benefited us more than that so-called wrongdoer."119 The "love of one's enemy," therefore, is not a sacrifice: the point is not to substitute oneself for the enemy, to die or condemn oneself to damnation in his place, but rather, to actualize in oneself the image of God and, at the same time, to leave the other alive in order not to preclude him from the possibility of achieving the same goal. ${ }^{120}$

The implication that what is "evil" for man is equally "evil" for God is articulated by Ibn 'Arabī when he argues for the possibility that God may not carry out His threat. God can only be praised by saying of Him what is praiseworthy per se (al-mahmū $d$ bi-l-dhāt), but this only applies to pardon (tajāwuz) and not to "sincerity in menace" (sidq al-waied), and God Himself says that He "overlooks their misdeeds" (yatajāwazu 'an sayyiātihim) (cf. Q 46:16). ${ }^{121}$ In this passage, as in the chapter on Jonah, where he hints at the parallelism between killing in retaliation and eternal damnation, Ibn 'Arabī argues against the eternality of punishment, equating it with a blameworthy form of retribution.

117 Hakìm, Mújam 296. On the contrary, those souls condemned to hell "love only those things fitting their nature." See Ibn 'Arabī, Futūhāàt ii, 330. See also 'Abd al-Qādir, Mawāqif ii, 935. According to Ibn 'Arabī, the prophets, who serve the divine "command" aiming at man's salvation, resist the divine decree, in the same way as the doctor who strives to save the invalid's life resists the law of nature. See Ibn 'Arabī, Fușūss i, 98.

118 Cf. Ibn 'Arabī, Futūhāt ii, 332-3, where Ibn 'Arabī distinguishes between natural love, which loves the beloved only to satisfy its own needs, and spiritual love, which loves the beloved for himself, also in his freedom not to love us. For Ibn 'Arabī the specific distinction between man and animal is not language, but the image of God. See Ibn 'Arabī, Futūhāt iii, 154 .

119 Ibid., iv, 47.

120 Cf. Ibn 'Arabī, Fușūṣ i, 168. See also Ibn 'Arabī's commentary on Noah's saying: "Lord, leave not a single soul of the unbelievers alive on the earth" (Q 71:26). Ibn 'Arabī states that "now perhaps, had they lived longer, they would have returned to God, or from their loins would have sprung men who would have believed in God, and brought delight to the believers." See Ibn 'Arabī, Futūhāat iv, 60 (trans. in Gril, Adab).

Ibn 'Arabī, Fuṣūṣ i, 93-4. See also idem, Futūḥāt iv, 46-7. 
Thus, one could think that the plea for the annulment of punishment in the hereafter cannot be extended to the case of the 'therapeutic' hudüd. However, in actual fact it is possible to intercede also for the annulment of temporary punishment:

In intercession, a servant, through his role of advisor (nāșih), upon seeing that God wishes to punish a man for his misdeed, says to Him: Oh Lord, You have urged us to forgive and made forgiveness a noble trait, preferable to taking revenge on the wrongdoer [...], You are more worthy of such ways [...]. Punishing evil is gainful only in this world, as the fulfilment of the hudüd wards off public harm (madarra 'ämma). Just as God is praised in this world $($ duny $\bar{a})$ for the institution of the hudūd [...], so is He praised in the next (ākhira) for His forgiveness. For hudüd in this world no intercession is possible, as they are God's rights; in the next, however, the common good (mașlaha) that here below wanted the application of the rights of God, no longer holds sway. In the case of men's rights, on the other hand, God Himself urged forgiveness. ${ }^{122}$

This passage is noteworthy as it sets out an asymmetry between dunya and akkhira: in the hereafter, the common good (maṣlaha) that calls for public criminal law no longer applies. Consequently, the legal principle upholding punishment in this world cannot be extended by analogy to the hereafter. Another passage hints that in the afterlife God punishes only the wrongs done to other creatures:

As the Lord (rabb) is He who restores (al-muṣlih), on Resurrection Day God will reconcile (yuslih) His servants with each other. Indeed, the Prophetic tradition tells of two men, one of whom has a claim to make against the other: they appear in front of God, and when the victim says: "Avenge me for the wrong he did to me," God answers: "Look heavenward!" The man sees there great goodness and says: "Whose is this, Lord?" And God answers: "It belongs to whoever can give me its price." So the man says: "Who could ever have that much?". So God says to him: "You will have that much if you forgive your brother." And he says: "I forgive him!" and takes him by the hand and they both enter paradise together. The Prophet, having told this story, said "Fear God and seek reconciliation between you as God will bring together His servants on the Day of Resurrection." But if God is so generous as to bring about reconciliation 
between His servants in such a way that the victim renounces his right, it goes without saying that He too will renounce the rights He has in their regard. Indeed, God punishes whom He wills for wrongs done to others, but not for His own right (bi-haqqihi al-mukhtașs bi-hi). Associationism (shirk) is punished in as much as it is a wrong done to others. God does not stand up for Himself, but for others (mā yantașir li-nafsihi wa-innamā yantașir li-ghayrihi). On the Day of Resurrection the "associates" will disown their followers [cf. Q 2:166].123

In other words, idolatry, the ultimate crime against God, is not punished in order to safeguard a right of God, but because those who have been associated with God have been "wronged" by their followers, who attributed to them something they did not claim.

The benefit of forgiveness, which is "veiled" in this world, becomes evident in the next. Nevertheless, the victim is given the choice. In the tradition on righting wrongs in the afterlife reported by Ibn 'Arabī, God is not a forgiver but a conciliator (muslih): He does not annul the punishment by unilaterally bestowing grace. Rather, He reconciles the victim and the offender by paying the blood-money himself. ${ }^{24} \mathrm{~A}$ well-known version of this theme features David and Uriah: David is already on the pulpit at the gate of heaven reciting Psalms when Uriah grabs his robes claiming his right to retaliation. God, however, ransoms David by compensating Uriah with a number of castles in paradise. ${ }^{125}$ According to Ibn Ishāa (d. 150/767), this story answers a problem raised by the "People of the Book": if God pardons David, must one not deduce that his victim will have no justice? ${ }^{126}$ Al-Qurțubì (d. 671/1272), in reporting this story, stresses that the likelihood of God stepping forward as a conciliator comes about only for penitent wrongdoers, as David was, otherwise no one would go to hell (wa-law kāna dhälika fijamī al-nās mā dakhala ahad al-nār).127 In the same way, nobody would go to hell were one to take the following report attributed to the Prophet seriously: "On the Day of Resurrection, a herald will proclaim from beneath the Throne: Oh community of Muhammad, I forgive

\footnotetext{
123 Ibid., iii, 383: fa-inna al-shurakā' yatabarra'ūna min atbā'ihim yawm al-qiyāma.

124 The idea that God "funds" the settling of accounts in the afterlife also plays an important role in Mu'tazili thinking on compensation ('iwad). See Vasalou, Moral 80-1. Ibn 'Arabī's focus on "rights" is a continuation of this line of reasoning. Cf. ibid., 41-3, 60-2, 79-86.

125 Ghazālī, Durra 86-8.

126 Déclais, David 221. On the topic of the forgiveness of victims in the afterlife in Zoroastrianism and in rabbinical Judaism, see Winston, Iranian 213. See also above, n. 8.

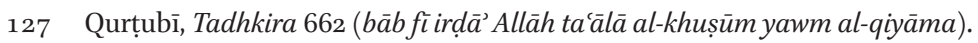


you whatever I could claim from you; as for the injuries which remain, forgive each other for them ( $f a$-tawāhabūhā $)$ and enter the Garden for My mercy."128

By suggesting that only crimes against other creatures, and not those against God, are punished in hell, Ibn 'Arabī exempts hell entirely from the reach of public penal law where the common good justifies state violence. Even where the sin does not appear to be transitive it impinges on the rights of "others": the rational soul, entrusted with "governing" one's animal soul (nafs) and the limbs of one's body, breaches their rights when it disobeys divine command, acting as a tyrant (wāli jāir) who forces his subjects to commit crimes. ${ }^{129}$ For Ibn 'Arabī, among sins, haughtiness (takabbur) is the first in line to be punished eternally in hell, Pharaoh being the archetype of this class of sin in the macrocosm. ${ }^{130}$ But every iniquitous soul is a "tyrant" in the microcosm, the focus of Ibn 'Arabì's interest, who shifts politics from the administration of others to the administration of oneself, from the common good to individual happiness. ${ }^{131}$

Even if punishment relates to the "rights of men" and not to the "rights of God," any wrongs committed against men are at the same time a wrong against God:

[In hell] there is hunger as God created it from the manifestation (tajalli $)$ of His word [reported] in the Șah̄h of Muslim: "I was hungry and you did not feed Me, I was thirsty and you did not quench My thirst, I was sick and you did not come to visit Me." This is the most awe-inspiring personal revelation through which God has descended among His servants in His gentleness towards them. Hell has been created from this reality. May God protect me and you all from it. ${ }^{132}$

Precisely because He is immanent, God 'suffers' sin and takes revenge-a reprisal not vitiated by mercy-but only for a limited spell: as long as it takes for Him to free Himself from His pain. ${ }^{133}$

128 Ibid.; cf. Ghazālī, Ihyyā’ iv, 530 ( $k$. dhikr al-mawt wa-mā ba'dahu, b. fì sa'at rahmat Allāh). Augustine had warned the "tender-hearted" not to interpret the Our Father in this way: "For He does not say, if ye forgive men their sins, your Father will also forgive you your sins, no matter of what sort they be" (De Civ. Dei 21.27.4).

129 Ibn 'Arabī, Futūḥāt iii, 76. This is also quoted in 'Abd al-Qādir, Mawāqif ii, 938; see also ibid., 934, 936.

130 Ibn 'Arabī, Futūḥāt i, 301.

131 Cf. Nyberg, Schriften 15-7. Ibn 'Arabī calls man, as microcosm, al-madīna al-fädila. See Ḥakīm, Mújam 1018.

132 Ibn 'Arabī, Futūḥāt, i, 297; Sha'rānī, Yawāqūt ii, 463.

133 Ibn 'Arabī, Fuṣūṣ i, 172. On the "suffering" of God, see also Ibn 'Arabī, Futūhāat ii, 206. 
In conclusion, Ibn al-Qayyim can help us better comprehend Ibn 'Arabï's eschatological ideas; things can be discerned through their opposites. The inhabitants of paradise comprehend their own felicity by contemplating the Fire, ${ }^{134}$ and in a similar way, an examination of Ibn al-Qayyim facilitates comprehension of Ibn 'Arabī's concept of universal salvation. Ibn al-Qayyim perfects political hell, taking the principle that violence is justified by the common good as far as logic will allow: in the eternal civitas the use of violence will no longer be necessary as enemies will be wholly reformed and reinstated in the normality of a single sound nature. Ibn 'Arabī downplays the political and legal aspect of hell, to the advantage of its ethical and spiritual values. The underlying principle is not mașlaha but happiness: the unshadowed joy of those who, by going beyond "nature" have actualized in themselves the image of God, and the "veiled" joy that can take on as many forms as there are temperaments and natures of men.

\section{Bibliography}

\section{$1 \quad$ Sources}

'Abd al-Qādir al-Jazāinīi: Kitāb al-mawāqif, 3 vols, Damascus 1967.

al-Ghazālī: Al-durra al-fäkhira fı̀ kashf ulūm al-ākhira, ed. and trans. Gautier, L.: La Perle Précieuse, Geneva 1878, repr. Amsterdam 1974.

: Ihyǟ'ulūm al-dīn, Cairo 1957, repr. Semarang n.d.

: Al-Maqșad al-asnā fı sharh må̄ñ̄ asmā’ Allāh al-ḥusnā, ed. Shehadi, F.A., Beirut 1982.

al-Harawī, 'Alī b. Sulțān al-Qārī: Al-Qawl al-sadīd fíjawāz khulf al-wa ìd, Tanta 1412/1992. Ibn 'Arabī: Fuṣūṣ al-hikam, ed. 'Afîfi, Abū l-'Alā, Beirut 1966, tr. Austin, R.W.J.: The bezels

of wisdom, New York 1980.

Ibn 'Arabī: Al-Futūhāat al-makkiyya, 4 vols, Cairo 1329/[1911], repr. Beirut [1968].

Ibn al-Jawzī: Talbìs Iblìs, Beirut 1403/[1982-3].

Ibn Qayyim al-Jawziyya: Hādī al-arwāh ilā bilād al-afrāḥ, Cairo n.d.

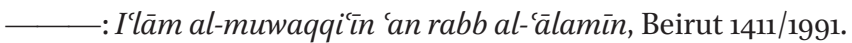

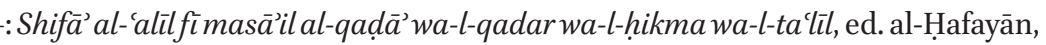

'U., Riyadh 1420/1999.

Ibn Taymiyya: Al-Siyāsa al-shariyyya fi iṣlāh al-rāic wa-l-rađiyya, [Riyadh] 1401/ [1980-81].

134 Cf. Chittick, Religious diversity $117-8$. 
Khayyām, 'Umar: Rubāiiyyāt, tr. Fitzgerald, E.: Rubáiyát of Omar Khayyám, ed. Karlin, D., Oxford 2009.

al-Nābulusī: Al-Qawl al-sadìd fí jawāz khulf al-waìd wa-l-radd 'alā al-rūmì al-'anìd, Süleymaniye Kütüphanesi, Esat Efendi 36o6, ff. 207b-224b.

al-Nasafî, Abū al-Mu'īn: Tabșirat al-adilla, ed. Salamé, C., Damascus 1993. al-Nawawī: Al-Minhāj sharḥ Șaḥịh Muslim b. al-Hajjāj, Beirut 1392/[1972-3]. al-Qayṣarī: Mațla'khuṣūṣ al-kilam fìma'ānīfușūṣ al-hikam, 2 vols, Qum n.d. al-Qurțubī: Al-Tadhkira fì aḥwāl al-mawtā wa-umūr al-ākhira, Riyadh 1425/[2004-5]. al-Shahrastānī: Al-Milal wa-l-nihal, Cairo n.d.

al-Sha'rānī: Al-Yawāqüt wa-l-jawāhir fì bayān 'aqā̉id al-akābir, Beirut 1419/1998.

Swedenborg, E.: Heaven and Hell: also the world of spirits, or intermediate state, from things heard and seen, Boston 1884.

al-Zamakhsharī: Al-Kashshāf 'an ḥaqāiq al-tanzīl, ed. al-Mahdī, 'Abd al-Razzāq, Beirut n.d.

2

\section{Studies}

Abrahamov, B.: The creation and duration of paradise and hell in Islamic theology, in Der Islam, 79 (2002), 87-102.

Ajhar, 'Abd al-Ḥakīm: Su'āl al-'ălam: Al-Shaykhān Ibn 'Arabì wa Ibn Taymiyya min fikr al-waḥda ilā fikr al-ikhtiläf, Casablanca 2011.

Addas, C.: Une victoire éclatante: Le Verus Propheta dans la doctrine d'Ibn 'Arabî, n.p. 2005 .

Arendt, H.: What is authority?, in Between past and future: Six exercises in political thought, New York 1961, 128-35.

Baschet, J.: Les Justices de l'Au-delà: Les représentations de l'Enfer en France et en Italie (XII ${ }^{e}-X V^{e}$ siècles), Rome 1993 .

Bauckham, R.: The fate of the dead: Studies on the Jewish and Christian apocalypses, Leiden 1998.

Berti, V.: Grazia, visione e natura divina in Nestorio di Nuhadra (m. 800 ca.), in Annali di Scienze Religiose (Dipartimento di Scienze Religiose-Università cattolica del Sacro Cuore), 10 (2005), 219-57.

Brague, R.: Au Moyen Âge: Philosophies médiévales en chrétienté, judaïsme et islam, Chatou 2006.

Chialà, S.: Dall'ascesi eremitica alla misericordia infinita: Ricerche su Isacco di Ninive e la sua fortuna, Firenze 2002.

Chittick, W.C.: Death and the world of imagination: Ibn al-Aarabī's eschatology, in $M W$, 78 (1988), 51-82.

Chittick, W.C.: Imaginal worlds: Ibn al-'Arabi and the problem of religious diversity, Albany 1994.

: The self-disclosure of God: Principles of Ibn al-'Arabı’s cosmology, Albany 1998. 
Chodkiewicz, M.: Un Océan sans rivages: Ibn Arabî, le Livre et la Loi, Paris 1992.

- : The banner of praise, in Journal of the Muhyiddin Ibn Arabi Society, 21 (1997), $45^{-58}$.

: Le procès posthume d'Ibn 'Arabī, in de Jong, F. and Radtke, B. (eds): Islamic mysticism contested: Thirteen centuries of controversies and polemics, Leiden 1999, 93-123.

Corbin, H.: L'imagination créatrice dans le soufisme d'Ibn 'Arab̄̄, Paris 1958.

Crone, P.: Abū Saīd al-Hadrī and the punishment of unbelievers, in JSAI, $3^{1}$ (2006), 92-106.

— : "No compulsion in religion": Q. 2:256 in mediaeval and modern interpretation, in Amir-Moezzi, M.A., Bar-Asher, M.M. and Hopkins, S. (eds): Le shī isme imāmite quarante ans après: Hommage à Etan Kohlberg, Turnhout 2009, 131-78.

Daley, B.E.: The hope of the early church: A handbook of Patristic eschatology, Cambridge 1991.

Déclais, J.-L.: David raconté par les musulmans, Paris 1999.

Donner, F.: Muhammad and the believers: At the origins of Islam, Cambridge MA 2010.

Eslin, J.-C.: L'Au-delà dans la vie de la cité: le rôle politique des peines de l'enfer d'après Hannah Arendt. Essai d'interprétation, in Revista Portuguesa de Filosofia, $5^{8}$ (2002), 255-69.

Feiz, R.: La notion de peine chez les sufis: l'école d'Ibn 'Arabi, in Archives de politique criminelle, 23 (2001), 131-9.

Feiz, Rezā: "Qahr mabțūn" va-jazā'ī nā-mațlūb dar 'irfān-i Ibn 'Arabī, in Nadjafī Abrandābādī, 'Alī Ḥusayn (ed.), Dā̉irat al-máārif-i ulūm-i jinā'ū, II, Tehran 2013, 1-20.

Gobillot, G.: La conception originelle: Ses interprétations et fonctions chez les penseurs musulmans (Cahiers des Annales Islamologiques, 18), Cairo 2000.

: Corps (badan), âme (nafs) et esprit (rūhn) selon Ibn Qayyim al-Ǧawziyyah à travers son Kitāb al-rūh: entre théologie rationnelle et pensée mystique, in Bori, C. and Holtzman, L. (eds): A scholar in the shadow: Essays in the legal and theological thought of Ibn Qayyim al-Jawziyya, in Oriente Moderno, 90 (2010), 229-58.

Griffel, F.: Apostasie und Toleranz im Islam: Die Entwicklung zu al-Gazālīs Urteil gegen die Philosophie und die Reaktionen der Philosophen, Leiden 2000.

Griffith, S.H.: Disputing with Islam in Syriac: The case of the monk of Bêt Ḥālê and a Muslim emir, in Hugoye: Journal of Syriac Studies, 3 (2000), 29-54.

Gril, D.: Le personnage coranique de Pharaon d'après l'interprétation d'Ibn'Arabī, in Annales Islamologiques, 14 (1978), 37-57.

: Adab and revelation: One of the foundations of the hermeneutics of Ibn 'Arabī, in Hirtenstein, S. and Tiernan, M. (eds): Muhyiddin Ibn Arabi: A commemorative volume, Shaftesbury 1993, 228-63. (http://www.ibnarabisociety.org/articles/ adabandrevelation.html) 
Guillaumont, A.: Conférence de M. Antoine Guillaumont, in Annuaire de l'École pratique des hautes études, Section des sciences religieuses, 88 (1979-80), 369-71.

Al-Ḥakìm, S.: al-Mu jam al-ṣūfi: al-ḥikma fi ḥudūd al-kalima, Beirut 1401/1981.

Hamza, F.: To hell and back: A study of the concepts of hell and intercession in early Islam, PhD Oxford 2002.

Hatem, J.: L'amour pur hyperbolique en mystique musulmane, Paris 2009.

Hoover, J.: Islamic Universalism: Ibn Qayyim al-Jawziyya's Salafi deliberations on the duration of hell-fire, in $M W, 99$ (2009), 181-201.

Hoover, J.: Ibn Taymiyya's theodicy of perpetual optimism, Leiden 2007.

- God's wise purposes in creating Iblīs: Ibn Qayyim al-Ğawziyyah's theodicy of God's names and attributes, in Bori, C. and Holtzman, L. (eds): A scholar in the shadow: essays in the legal and theological thought of Ibn Qayyim al-Jawziyya, in Oriente Moderno, 90 (2010), 113-34.

Johnson, A.: Jesus and Moses: Rabbinic backgrounds and exegetical concerns in Matthew 5 as crucial to the theological foundations of Christian ethics, in Inch, M. and Youngblood, R. (eds): The Living and Active Word of God, Winona Lake 1983, $85^{-108 .}$

Khalil, M.H.: Islam and the fate of others: The salvation question, Oxford-New York 2012. Knysh, A.: Ibn 'Arabi in the later Islamic tradition: The making of a polemical image in medieval Islam, New York 1999.

Lane, E.W.: Arabic-English lexicon, 8 vols, London 1863-93.

Lange, Ch.: Justice, punishment, and the medieval Muslim imagination, Cambridge 2008.

— : Sitting by the ruler's throne: Al-Ghazālī on justice and mercy in this world and the next, in Serrano, D. (ed.): Narrary suscitar: violencia, compasión y crueldad en la literaturaárabo-islámica, Madrid 2011, 131-48.

—- Sins, expiation and non-rationality in Hanafī and Shāfīi fiqh, in Gleave, R. and Reinhart, K. (eds): Islamic law in theory: Studies on jurisprudence in honor of Bernard Weiss, Leiden-Boston 2014, 143-75.

Le Goff, J.: La naissance du purgatoire, Paris 1981, tr. La nascita del Purgatorio, Turin 1996.

Mackenzie, M.M.: Plato on punishment, Berkeley 1981.

Al-Manā'ī' 'Ầisha bint Yūsuf: 'Aqīdat fanā' al-nār bayna Ibn 'Arabī wa-Ibn Taymiyya waIbn al-Qayyim, in Majallat markaz buḥüth al-sunna wa-l-sīra (University of Qatar), 11 (2004), 85-141.

Massignon, L.: La passion de Husayn Ibn Mansûr Hallâj, martyr mystique de l'Islam, exécuté à Bagdad le 26 mars 922: Étude d'historie religieuse, new ed., 4 vols, [Paris] 1975.

Nyberg, H.S.: Kleinere Schriften des Ibn al-'Arabï, Leiden 1919.

O’Meara, D.J.: Platonopolis: Platonic political philosophy in Late Antiquity, Oxford 2005. 
Pagani, S.: Imago dei e interdizione di uccidere nell'Islam: Il capitolo su Giona dei Fusūs al-hikam di Ibn 'Arabī, in Melloni, A. and Saccenti, R. (eds): In the image of God: Foundations and objections within the discourse on human dignity (Proceedings of the colloquium Bologna and Rossena [July 20o9] in honour of Pier Cesare Bori), Berlin 2010, 227-61.

: Vane speranze, false minacce: L'Islam e la durata dell'inferno, in Migliore, M.C. and Pagani, S. (eds): Inferni temporanei: Visioni dell'aldilà dall'estremo Oriente all'estremo Occidente, Roma 2011, 179-222. (French translation:Vains espoirs, fausses menaces: L'islam et la durée de l'enfer, in Aubin-Boltanski, E. and Gauthier, C. (eds): Penser la fin du monde, Paris 2014, 281-302)

Peters, R.: Crime and punishment in Islamic law: Theory and practice from the sixteenth to the twenty-first century, Cambridge 2005.

Radtke, B.: Theosophie (hikma) und Philosophie (falsafa): Ein Beitrag zur Frage der ḩikmat al-mašriq/al-išrāq, in Asiatische Studien/Etudes asiatiques, 42 (1988), 156-174.

Reinink, G.J.: Origenism in thirteenth-century northern Iraq, in Reinink, G.J. and Klugkist, A.C. (eds): After Bardaisan: Studies on continuity and change in Syrian Christianity in honor of professor Han J.W. Drijvers, Leuven 1999, 237-52.

Reynolds, G.S.: A medieval Islamic polemics against certain practices and doctrines of the East Syrian Church: Introduction, excerpts and commentary, in Thomas, D. (ed.): Christians at the heart of Islamic rule, Leiden 2003, 215-30.

Ritter, H.: Das Meer der Seele, tr. O'Kane, J.: The ocean of the soul: Man, the world and God in the stories of Farìd al-Dīn 'Atțār, Leiden 2003.

—: Muslim Mystics Strife with God, in Oriens, 5 (1952), 1-15.

Roig Lanzillotta, L.: Does punishment reward the righteous? The justice pattern underlying the Apocalypse of Peter, in Bremmer, J.N. and Czachesz, I. (eds): The Apocalypse of Peter, Leuven 2003, 127-57.

Rowell, G., Hell and the Victorians: A study of the nineteenth-century theological controversies concerning eternal punishment and the future life, Oxford 1974.

Swanson, M.: Ḥanūn ibn Yūḥannā ibn al-Ṣalt, in Thomas, D. and Mallett, A. (eds): Christian-Muslim relations: A bibliographical history, vol. II, 900-1050, Leiden 2010, 158-62.

Thomas, D.: Christian doctrines in Islamic theology, Leiden 2008.

Urvoy, D.: Les penseurs libres dans l'Islam classique, Paris 1996.

Vajda, G.: À propos de la perpétuité de la rétribution d'outre-tombe en théologie musulmane, in $S I, 11$ (1959), 29-38.

van Ess, J.: Das begrenzte Paradies, in Salmon, P. (ed.): Mélanges d'islamologie: Volume dédié à la mémoire de Armand Abel par ses collègues, ses élèves et ses amis, Leiden 1974, 108-27. 
des religiösen Denkens im frühen Islam, Berlin-New York 1991-97.

Vasalou, S.: Moral agents and their deserts: The character of Mu'tazilite ethics, PrincetonOxford 2008.

Walker, D.P.: The decline of hell: Seventeenth-century discussions of eternal torment, London 1964.

Winston, D.: The Iranian component in the Bible, Apocrypha and Qumran: A review of the evidence, in History of Religions, 5 (1966), 183-216. 